\title{
前白血病の研究 (抄録)
}

\section{京都大学医学部内科第一講座 内野治人}

\section{はじめに}

内科臨床の目的は，内科疾患の診断と治療にあるこ とはいらまでもない.最近の診断技術や病態生理の解 明は，疾患の診断基準の設定に賣献し，加類縁疾患 の鑑別診断を明確にしてきたといえよう。その様な疾 患概念の設定に伴い，东ず診断がつけられ，ついでそ れぞれに対する治療法の手順がプロトコールとして設 けられつつある。内科疾患は，その疾患病態により， 可逆性と不可逆性の場合があり，治療は前者では治瘜 を目的とし，後者の場合は，疾患病変自体は不可逆性 であっても，その進行を停止させるか，あるいは詨症 的であってもコントロールして，患者の苦痛をとりさ り，日常の社会生活を円滑に行い得る様にする工夫が なされる、この様な進歩の中にあって，当然内科医は 内科疾患の早期発見と早期治療を目的とする様になる のは当然のことであろう。早期発見は，早期であれば まだ可逆性にある疾患を，不可逆性に進展する前に治 療して進行を停止ないし治瘱させ得るからである，最 近は各内科専闍領域における内科疾患において，この 様な方向入向けて鋭意努力が払われ，その成果があが りつつあることも周知の所であろら。

一方，内科突患全般に対して，予防して，一定の疾 患を個体に発症させない方向での研究が進歩し，これ は健康管理ないしは保健とい5目的に向っての努力で あり，その進歩により，日常の生活，環境など多方面 での健康管理が進められつつある。この問題に関して は公衆衛生学的ないしは疫学的知見に基ついて，個 令 の人に対して疾患の予防が計画されつつある。勿論ま だ不充分の所も多くあり，多彩で多種の内科矤患に対 して,個々の予防対策が完成されているわけではない. ことにがん一悪性腫湯一の予防が現在最も関心が高 く，かつ努力が払われている一つの領域といってよい であろら。

以上のベた二方向からのアプローチの中間に位置す るものと考えられるるのとして，悪性腫瘍の早期発見 という時点よりさらに以前の状態の把握という問題と
した前癌状態のい5すのが最近注目をあびている所で ある.ここに前癌状態の一つとしての前白血病につい てのわれわれの研究の過程と成果をのべるとともに， その内科疾患臨床とのかかかりを考察することとす る。

\section{前癌状態としての前白血病}

前癌状態とは，ある一定の葴器に病変があり，その 時点では現在の知識下に扣いて, 癌と診断し得ないも のであって，時間的経過とともに，癌に進展する可能 性が高いもの索いう。しかし，健康人において精密検 䛦下で, 癌検診を行うことは全てについてスクリーニ ングとしても困難が多い。しかし，一定の症状があっ たり，あるいはない場合でも患者の希望により特定葴 器にのみ重点を扎いて検骖を行うことは，比較的容易 に行い得る所であるし，早期発見のための検診として 行われている、一般に疫学的，統計的にある病変が癌 化しやすいといら知見があったとしても，その個体に おいてその病変をどの様に追跡して行くかといら問題 は，個々の疾患により千差万別といわざるを得ないで あろう。そこには，内科臨床で一般的によく使われる 言莱「様子を，あるいは経過を見ましょら」とい5時 間的要素を入れた追跡follow-upが必要となる所であ 万5.

前白血病の研究は，ある血液異常をるっている患者 を追跡診療中に，突然急性白血病を発症した症例の， retrospectiveな観察記載から導入された概念である。 前白血病preleukemiaといら術語が始めて使用された のは，1953年のBlockらによる報告であり，わが国で は，1954年に天野らにより要急性原爆障害例の剖検に おいて, 前白血病性結節増殖とい5記載が行われてい るのが始めであろう。

その後血液学の進歩, すなわち，診断技術の進歩， 疾患の病態，概念の整理，確立などととも白血病と しては非定型的なもの，low percentage leukemia (1958), smoldering leukemia (1963), atypical leukemia (1966)などの漠然とした概念から，また一方，再 
生不良性貧血としては非定型的なもの，不応性賓血 refractory anemiaなどの概念が提唱され，整理され た。芽球過鄱を伴う不応性筫血 refractory anemia with excess of blasts (RAEB) が1970に提唱され, その概念設定に至り，その間に個々の症例の報告が集 積された。そそこで国際的に関心を呼び，初めての国際 シンポジゥムが1975年パリで開催され，前白血病状態 preleukemic states-hemopoietic dysplasia (HPD) と いら概念が承認されるに至った。この時点では, retrospectiveな研究から，白血病発症を指向する各種の 血液学的指標が整理され，その様な所見を認める一群 の血液異常を prospective 飞みて行く場合に hemopoietic dysplasia と呼ぶことがまとめられた。一 方, 1982年に至り, 急性白血病の臨床病型分類の整理 が, フランス，米国，英国French-American-British (FAB) の血液学者グループにより行われて，FAB分 類とされたが，その時に前白血病といら概念をこえて， むしろ急性白血病という概念に適合しない疾患群とし て, 骨髄異形成症候群 myelodysplastic syndrome (MDS)がまとめられたことはよく知られている.

\section{前白血病と myelodysplastic syndsome}

白血病の前癌状態として前白血病を理解する場合に は, 広義には白血病を造血藏器の腫湯と理解する場合 と狭義に白血病のみを考方る場合の二方向にわけられ る. 造血臓器での造血細胞系列は骨髓系とリンパ系と にわけられるが，狭義の前白血病は急性骨髄性白血病 の前状態であるので, 骨䯣系の前白血病の範畴に入る が, リンパ系腫煬については，前リンパ腫 prelymphoma といら概念があり,リンパ系列といら意味で前 骨髄腫premyeloma この中に入れられる。

前リンパ腫は, 墨性リンパ腫の概念の整理, 診断基 準の設定, 症例の増加などの中にあって，長期間にわ たる症例追跡により，一定の条件づけられた状態から のリンパ腫の発症が明らかになりつつある，前骨鬴腫 もM-タンパクといら指標によって, 内科臨床での一般 のルーチン検査としての血浆タンペク分画像解析の普 及とその成績の集積から，骨髄腫の前状態としての条 件づけが明らかになりつつある。たとえば，遺伝的素 因, ウイルス感染，自己免疫疾患などが知られている。 しかし，現時点では，high riskといら意味での腫瘍化 の傾向は把握されても，個々の症例について，ょり看 瑝化を示す所見やその予後, 腫場化の比率などはまだ 明らかでないといってよい。
狭義の急性白血病発症前という意味での前白血病に は，三群の考之方がある．第一群はいわゆるhigh risk 群であり，先天性の染色体異常を伴ら一群の疾患があ ザられるし，放射線被曝例もこれに含まれる，第二群 は，定義的には急性白血病とはいわないが，造血組織 の增殖性疾患があり, 骨䯣線維症や真性赤血球增加症 などがある、第一群は疫学的な意味でのhigh risk群で あり，第二群は造血組織の増殖性疾患といら点で白血 病に極めて近い疾患といらべきであろう。そこで第三 群としての一群のものが臨床的に重要となる。すなわ ち，（1）急性非リンパ性白血病の発症に先立ち, 臨床 的に何らかの血液異常のあること，(2) 白血病発症の high riskの条件づけがある場合にも，現時点で臨床的 に健康な人は除く，（3）いわゆる骨䯣堌殖性疾患は除 く，(4) 先行する血液異常が一定期間以上，少なくと す 1 力月以上, 大体 6 力月から 1 年以上持続している こと，の 4 条件をみたするのである。この前白血病の 概念は，急性白血病を発症した症例での発症以前に血 液異常を認めた症例を集積して, retrospectiveによと めた結論であって，このことからprospectiveに症例を 追跡することが可能となってきた。それら血液異常の 疾患名は再生不良性負血, 発作性夜間血色素尿症, 鉄 芽球性賓血，さらに不応性貧血などであった。一方， この間にあって前白血病という概念は，疾患名といら より,一つの疾患状態を示す概念であると考えられて, 多くの名称が提唱されてきたが，芽球過剩を伴ら不応 性賓血refractory anemia with excess of blasts, (Dreyfus)を主軸とする一群の疾患が，Dysmyelopoietic syndrome (Sultan) が始まって概念の变遷 を経たのち，その中のmoelodysplastic syndrome (MOS) が1982年FABグループによりまとめられた。 この概念は，不応性賓血 refractory anemia（RA）と 呼ばれる疾患群が三群あり，さらに慢性骨䯣単球性白 血病と呼ばれる特異な疾患を含んでまとめられてい る.RAとしては, 狭義のRA, 鉄芽球を伴らRA, refractory anemia with ringed sideroblasts (RARS), 芽 球過剩を伴うRA, refractory anemia with excess of blasts (RAEB) とその白血病への移行型RAEB in transfarmationにわけられている。

\section{前白血病の臨床的, 血液学的特徵}

前白血病として，急性白血病発症以前に何らかの血 液異常を認めた症例を，わが国で調查すると，再生不 良性負血と診断された例が大部分を占めている，再不 
貧の診断から， $1 \sim 4$ 年の間に白血病化しており，急 性骨䯣性白血病を発症することが多い。これらの症例 について白血病発症以前の血液像（末梢血液像衫よび 骨髄像）を検討した結果，特徽のある血液所見のある ことが明らかとなった。その研究結果から，前白血病 としての可能性を与元しめる多くの血球形態異常があ げられるが，それとともに，末梢血に括いて汎血球减 少症pancytopeniaがあることや，李たは血球三采統あ るいは少なくとも二系統の血球減少症bicytopeniaの あること，血球の形態異常は血球各系統いずれか，ま た二，三系統にあること，骨髄中の芽球および前骨䯣 球は $20 \%$ 以下であること, これらの所見が少なくとも 6 力月以上持続して, いわゆるsteady stateであること などが明らかとなった，これらの臨床的，血液学的所 見は, FABダループのMDSの概念のうち， RA, RARS，RAEBにあてはまるすのであって，MDSの前 白血病としての意義が確認されたといえよう.しかし， これら三疾患は，いずれも単一疾患といらことができ るか否かは尚不明確な所が多いし，実際わが国に拈け る，500例に及ぶこれら三疾患の予後調査により，白血 病発症率はRAで25.6\%, RARSで10.4\%, RAEBで $71.1 \%$ あることが判明した。すなおち，RAEBはそ の半数以上の症例が，その初猃から 2 年以内に白血病 化しているのに対し，他の二型は必ずしも全例白血病 化するむのではないことが明らかとなった。しかし， 血球减少のため, 出血, 感染により, 白血病化しない 場合でも，扔の拈のの50\%生存期間は，RAで44力月， RARSで41力月, RAEBで16力月であった. 因みに，さ きにretrospectiveな研究から，前白血病として再生不 良性責血が多いことをのべたが，逆に，わが国に括け る再生不良性賓血の多数例の長期予後調查に上れば, その白血病発症率は $0.3 \sim 2.6 \%$, 発作性夜間血色素尿 症で $2.4 \%$ であり，ここにあげた不応性貧血（RA）の
一群は, その型によって白血病化率には差があるにせ よ，より白血病を発症しやすい一群の疾患であること を明らかにすることができたとい充よう。

以上のことから, 前白血病としての研究は, 単なる retrospectiveの研究から, 不応性負血の研究に進み, その結果から，より白血病化しやすい症例を，一定の 診断基準のもとで，抽出することが可能となり，その ためのスクリーニング,ささらに確定診断の設定にまで 進んだ.現在の最も重要な問題は治療法の設定であり, 以上の研究から, 病型, 疾患群についての予後からの low risk, high riskの鑑別などにより，きめこまかい 治療対策が現在試みられつつあり，近いうちにその方 法の確立が期待される.

\section{おわりに}

前白血病の研究を通じて, 前癌状態の研究の一面を 明らかにして, 臨床的に個々の症例について, その悪 性腫瘍化の可能性を知る指標を整理することができ た。この研究を通して, 内科疾患の診療に招いて，あ る断面での静的な症例の観察のみではなく，その個体 の記録をchronologicalに追跡調査することの必要性 と，その記録をふりかえって，retrospectiveに，その 時, その時に沶いて, 開発された新しい技術で見な扔 すことができる様，記録のみならず，標本，資料なと の保存が重要であることが強く感じられた，単なる血 液標本（末梢血のみならず, 骨䯣塗抹標本）の，個及 の症例に括ける長期に一-10年以上にわたる一さかのぼ り得る保存が,この研究を可能にしたといえよ5, retrospectiveな成績を集積しつつ，そこから，一定の，一 般化し得る規準をとり出し, 抽出し，次にprospective に，その規準を個々の症例に適応しつつ，その妥当性 を評価して行くという臨床研究の一つの方向を示し得 たものと考える.ここに前白血病研究を通して得た内 科疾患の臨床研究のあり方を考察したものである. 